\title{
Agroforestry species of the Bolivian Andes: an integrated assessment of ecological, economic and socio-cultural plant values
}

\author{
Regine Brandt • Heike Zimmermann • \\ Isabell Hensen · Juan Carlos Mariscal Castro • \\ Stephan Rist
}

Received: 20 September 2011/Accepted: 23 February 2012/Published online: 9 March 2012

(C) Springer Science+Business Media B.V. 2012

\begin{abstract}
Agroforestry is a promising method for enhancing land-use sustainability in the Bolivian Andes. However, its benefits in terms of rural development are under-recognized due to gaps in understanding users' perceptions while taking into consideration both local and global environmental goals. Our study aimed to narrow these gaps by developing an analytical framework for analyzing the site-specific socio-ecological factors and interactions related to local woody species and assessing their ecological, economic, and sociocultural plant values in order to identify the most promising agroforestry species. The framework was then tested in an indigenous community at 2,760-3,830 $\mathrm{m}$ a.s.l.,
\end{abstract}

Electronic supplementary material The online version of this article (doi:10.1007/s10457-012-9503-y) contains supplementary material, which is available to authorized users.

R. Brandt $(\bowtie) \cdot$ H. Zimmermann $\cdot$ I. Hensen Institute of Biology/Geobotany and Botanical Garden, Martin-Luther-University Halle-Wittenberg, Am Kirchtor 1, 06108 Halle (Saale), Germany e-mail: regine.brandt@botanik.uni-halle.de

J. C. Mariscal Castro

Agroecología Universidad Cochabamba (AGRUCO), Universidad Mayor de San Simón (UMSS),

Avenida Petrolera Km. 4 1/2, Cochabamba, Bolivia

S. Rist

Centre for Development and Environment (CDE), University of Bern, Hallerstrasse 10,

3012 Bern, Switzerland incorporating vegetation surveys, environmental studies, and interviews on plant functions. Ecological, economic, and socio-cultural values and the ecological apparency of plants were calculated, and detrended correspondence and principal component analyses helped to reveal the socio-ecological context of significant factors for plant distribution and uses. Results showed dominating seral woody species along an altitudinal gradient. Although shrubs were more ecologically apparent than trees, trees were perceived to be more valuable as the usefulness and cultural importance of species increased with plant height and timber availability. Phytosociological factors played a minor but still significant role in perceived usefulness. Schinus molle and Prosopis laevigata ( $<3,200 \mathrm{~m}$ a.s.l.), Polylepis subtusalbida (>3,200 m a.s.1.), and Baccharis dracunculifolia (both zones) were evaluated as most promising for agroforestry use. In conclusion, our analytical framework proved to be a valuable tool for context-specific agroforestry plant selection. Nonetheless, economic, technical, and socio-cultural limitations of cultivating native agroforestry species were revealed as well. Agroforestry science and practice should, therefore, focus on enhancing reproductive potentials of existing woody vegetation, as well as problem-oriented horizontal dialogues between indigenous, expert, and scientific actors.

Keywords Agroforestry - Bolivian Andes · Local knowledge $\cdot$ Native woody species .

Quantitative ethnobotany ·

Socio-ecological plant values 


\section{Introduction}

Agroforestry is a traditional Andean land-use practice dating back to pre-colonial times (before 1530) when trees and shrubs were planted in agro-pastoral landscapes for use as timber and firewood as well as for improving soil productivity and stabilizing hillsides and terraces (Chepstow-Lusty and Winfield 2000). Since the 1980s, many development projects have proposed to revitalize Andean agroforestry due to its potentials for enhancing land-use sustainability, and for this purpose promoted the use of native woody species in traditional agrisilvicultural systems (trees and crops) such as hedgerow intercropping, barrier hedges for soil erosion control, and shelterbelts, as well as silvopastoral systems (trees on pastures) (e.g., Reynel and Léon 1990). However, experiences have shown that native trees are rarely cultivated in the farming systems of the Bolivian and Peruvian Andes (e.g., Chepstow-Lusty and Winfield 2000; Ibisch 2002). Instead, monoculture plantations of fast-growing exotic trees are predominant in forestry and, consequently, in peasant livelihoods (Luzar 2007). Species of exotic Eucalyptus are the most popular, but they are heavily criticized due to their allelopathic effect on crops (Ahmed 1989) and understory vegetation (Zhang and $\mathrm{Fu} 2009$ ), depletion of soil nutrients and water (Kidanu et al. 2005), and potential invasiveness (Richardson et al. 2004). Thus, Eucalyptus timber production tends to conflict with environmental agroforestry goals related to the conservation of soils, water, and biodiversity (Jose 2009; McNeely and Schroth 2006). Similarly, attempts to introduce agroforestry aiming exclusively at producing environmental services fail as well if peasants cannot derive any socio-economic benefits (Alavalapati et al. 2004). In order to be feasible and attractive for land users, agroforestry must provide favorable cost-benefit ratios within the given socio-ecological context (Gausset 2004), consider users' socio-cultural perceptions, and aim for compatibility with local livelihoods (Reed 2007).

Considering agroforestry from an actor-oriented perspective thus becomes a precondition for successful agroforestry. This requires evaluating contextspecific subsistence, commercial, and socio-cultural functions of agroforestry plants used (Madge 1995), by analyzing, among other things, peasants' plantrelated knowledge and values, which in turn are linked to their perceptions and behavior with respect to plant use and management (Saunders et al. 2006). In this regard, Garibaldi and Turner (2004) suggest focusing on species with outstanding socio-cultural values, which they refer to as "cultural keystone species", defined as "culturally salient species that shape in a major way the cultural identity of people, as reflected in the fundamental roles these species have in diet, materials, medicine, and/or spiritual practices" (Garibaldi and Turner 2004, no page number). Applying cultural keystone species may motivate land users to support conservation and restoration initiatives, including agroforestry. According to Turner (1988), the more widely a plant is used (intensity of use) and the more use of this plant valued (quality of use) and directed towards this specific plant rather than towards any other (exclusivity of use), the higher the plant's socio-cultural value. In contrast, negative plant attributes such as toxicity reduce perceived socio-cultural plant values. In general, the degree to which a species is used and valued depends on this species' biological plant attributes (traits) and on how well these traits and their functions are known and recognized by the users. This, in turn, is determined by the degree to which these functions match with actors' plant-related needs and priorities (Gausset 2004). Moreover, ecological plant attributes can influence users' behavior according to the "ecological apparency hypothesis". Adapted to ethnobotanical research by Phillips and Gentry (1993b), this hypothesis suggests that species which are frequent and dense and large in appearance are more visible and more readily available (i.e., more ecologically apparent), and therefore more likely to be used than less apparent plants. Rare or poorly accessible plants do not necessarily have low socio-cultural values, but compared to more apparent plants they must provide higher-quality or more exclusive uses that offset their low ecological apparency (Turner 1988).

From the point of view of sustainable agroforestry, a basic problem related to the concept of cultural keystone species is that high socio-cultural plant values are not necessarily compatible with high ecological plant values. The cultural keystone species approach is thus only useful for conservation purposes if it is expanded to incorporate the assessment of potential positive and negative effects of plants on soil, water, and biodiversity. For example, exotic species that bear the risk of becoming invasive need to 
be evaluated in terms of their negative effects on biodiversity (Nuñez and Simberloff 2005). However, knowledge gaps regarding the prediction of exotic invaders' likeliness to threaten native biodiversity and ecosystem functions (Kolar and Lodge 2001) call for using native agroforestry species in order to prevent invasions. Moreover, reforestation with native woody species can contribute significantly to restoring and conserving biodiversity (Jose 2009), which is of high significance in the Bolivian Andes given that natural woodlands remain only in the form of relicts (Hensen 2002; Navarro and Maldonado 2002). Besides supporting biodiversity conservation goals, agroforestry species should also possess soil-enriching and soilstabilizing capacities (Jose 2009) that could help to mitigate widespread and critical soil degradation problems in the Bolivian Andes (Zimmerer 1993).

Against this background, potential agroforestry species need to meet context-specific criteria simultaneously regarding ecological, economic, and sociocultural sustainability. Although the need for assessing agroforestry species from an integrated perspective has been recognized (e.g., Jose 2011), previous research focuses either on evaluating ecological plant attributes such as growth and survival (e.g., Butterfield 1995; Mahboubi et al. 1997) or on describing plant uses (e.g., Langenberger et al. 2009). Quantitative techniques were developed and applied for determining use values (e.g., Bennett and Prance 2000; Phillips and Gentry 1993a), cultural values (e.g., Garibaldi and Turner 2004; Tardío and Pardo-de-Santayana 2008) and the ecological apparency of plants (e.g., Lucena et al. 2007). Assessing conservation status, albeit considering habitat rather than single species (Hernando et al. 2010), is another example for a quantitative evaluation using ecological criteria. McDonald et al. (2003) did an integrated evaluation of plants' usefulness and ecological attributes, but without using quantitative techniques. A quantitative tool suitable for an integrated and context-specific assessment of agroforestry species is thus not yet available.

The aims of the present study were to develop an analytical framework for analyzing the site-specific socio-ecological factors and interactions related to local woody species, and to test it by calculating ecological, economic, and socio-cultural plant values as a basis for identifying the most appropriate agroforestry species in an indigenous peasant community of the Bolivian Andes. We addressed the following research questions: (1) What is the floristic composition of local woody species, and what are the determining environmental factors? (2) Which species' functions are important to local livelihoods, and which factors control species' uses? (3) Which species provide the highest ecological, economic, socio-cultural, and integrated values for agroforestry under the local conditions? Examination of these questions was followed by a discussion on the implications for applied community-based agroforestry.

\section{Study site}

The pilot study for testing our analytical framework took place in the Quechua-speaking indigenous community Tres Cruces $\left(17^{\circ} 28^{\prime}-17^{\circ} 30^{\prime} \mathrm{S}, 66^{\circ} 27^{\prime}-66^{\circ} 29^{\prime}\right.$ $\mathrm{W}, \sim 850$ ha, 2,760-3,830 $\mathrm{m}$ a.s.l.), situated in the municipality of Tapacarí, Cochabamba, Bolivia. This semiarid region receives an average of $600 \mathrm{~mm}$ of annual precipitation, with $>80 \%$ of the rainfall occurring between November and March (Ramadas No. 401-17, 1971-2003, Bolivian National Meteorology and Hydrology Service, SENAMHI). Annual mean temperature is about $11^{\circ} \mathrm{C}$ (Honorable Alcaldía Municipal de Tapacarí 2003). According to Navarro and Maldonado (2002), the study area extends over the biogeographic Peruvian Puna Province (in transition to Bolivian-Tucuman Province). Native woody vegetation consists of hedges and shrublands at field margins, on waysides and stony terrace walls, in ravines, and on fallow land.

The peasant population mainly depends on smallscale subsistence farming based on the production of tubers such as Solanum tuberosum, cereals (e.g., Zea mays, Triticum sativum, Chenopodium quinoa), legumes, vegetables, and fruits. The rearing of livestock (ovine, caprine, bovine) complements agricultural activities. More than $60 \%$ of the communal territory is affected by hydric soil erosion, which endangers agro-pastoral productivity (Aguilar and Bracamonte 2002). This led to the establishment of soil conservation measures (e.g., terraces, dams) complemented with agroforestry systems of native and exotic trees and shrubs (e.g., Buddleja coriacea, Spartium junceum) such as hedgerow intercropping and barrier hedges, boundary plantings, and shelterbelts in the course of a participatory rural development project (1999-2002). Moreover, family fruit orchards 
with peach (Prunus persica) and exotic tree plantations (Eucalyptus globulus, Pinus sp., Cupressus sp.; $>3,600 \mathrm{~m}$ a.s.1.; $\sim 15 \mathrm{ha}$ ) for timber and firewood production were cultivated.

\section{Methods}

We constructed an analytical framework in order to analyze the site-specific socio-ecological factors and interactions related to local woody species. For this purpose, we carried out vegetation surveys and environmental studies, as well as ethnobotanical data sampling and classification. The results provided the basis for calculating the context-specific ecological, economic, and socio-cultural plant values in order to identify the most appropriate agroforestry species for the study area. We concluded our analyses by combining environmental site variables and plant values to identify the significant factors controlling local floristic compositions and plant uses (Fig. 1).

Vegetation surveys and environmental studies

In the first phase of our study, we determined the distribution, dominance, height, and floristic composition of woody species growing in the community of Tres Cruces. In addition, we analyzed environmental variables (see below) of the study plots. Vegetation surveys were conducted in 42 plots ranging from 2,816 to 3,774 m a.s.l. between November 2005 and January 2006, during the rainy season. Sampling was spatially organized according to three agro-ecological production zones as defined by local peasants: ura, situated below 3,200 m a.s.1.; chawpi, situated at 3,200-3,500 m a.s.l.; and pata, situated above 3,500 $\mathrm{m}$ a.s.l. In each zone, we randomly selected 14 plots with woody vegetation. As we focused on naturally growing species, exotic tree

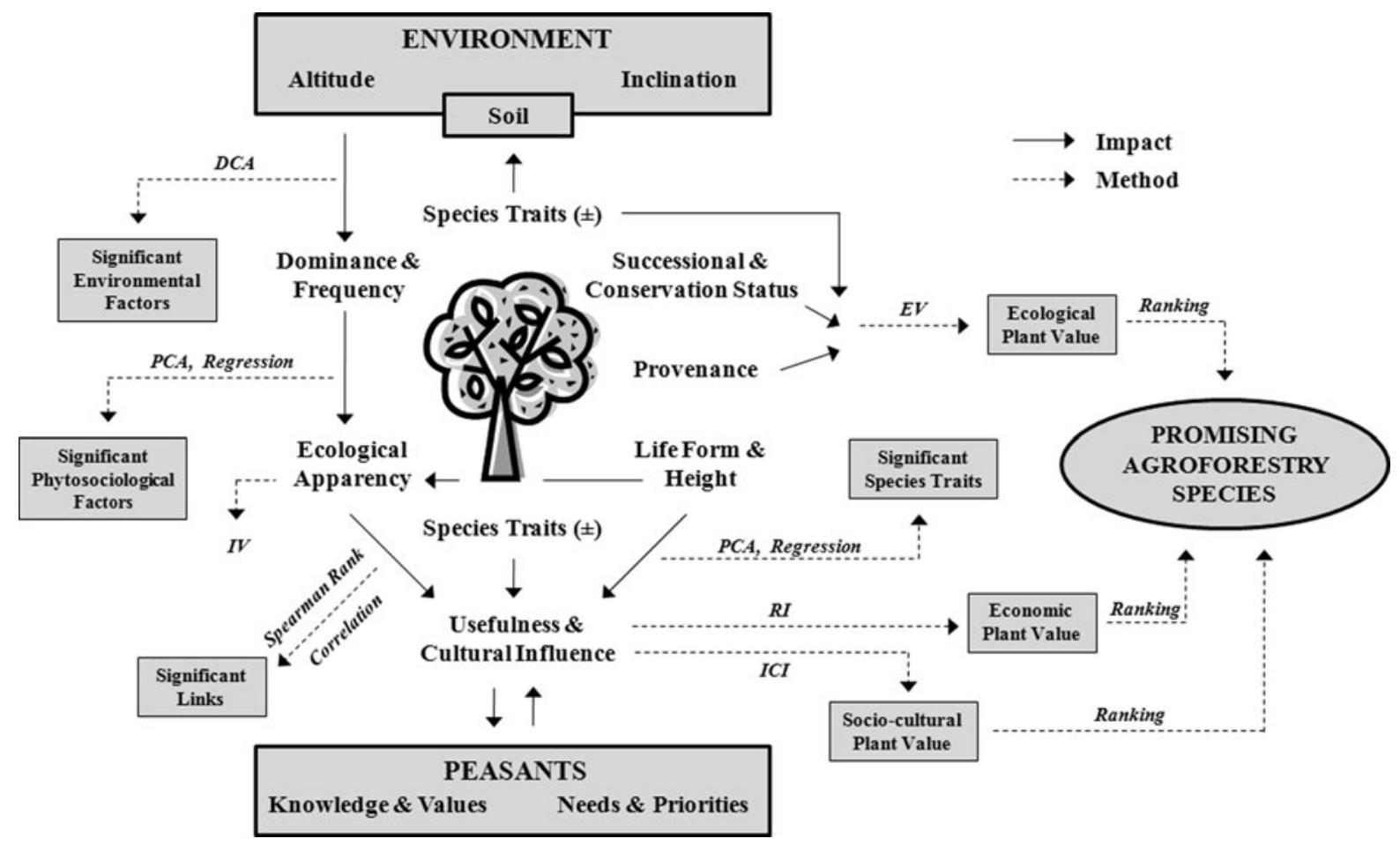

Fig. 1 Analytical framework of woody plant-related socioecological interactions for identifying promising agroforestry species, based on ecological and ethnobotanical indices applied in our study (in italics): $E V$ ecological plant value, $R I$ relative importance, ICI identified cultural influence. Statistical methods applied in our study (in italics): detrended correspondence analysis (DCA) for analyzing significant environmental factors for floristic composition of woody plants; principal component analysis (PCA) and linear regression analysis for determining significant species traits for usefulness of woody plants; Spearman rank analysis for calculating correlations between ecological apparency (Importance Value [IV]), usefulness (RI) and cultural influence (ICI) 
plantations were not considered. In order to comply with criteria of structural and floristic homogeneity of vegetation units, we defined different plot sizes for shrublands (30-100 $\mathrm{m}^{2}$ ) and hedges on terrace walls or waysides $\left(20-60 \mathrm{~m}^{2}\right)$. Geographic position, altitude, and exposition of plots were measured using a handheld GPS device (GARMIN Geko 201); inclination was estimated. A mixed topsoil sample of six subsamples $10 \mathrm{~cm}$ in depth was taken for each plot, except for plots on stony terrace walls $(n=3)$. We identified woody species (trees, shrubs, subshrubs, perennial herbs, and vines with woody stems) with a height $\geq 0.5 \mathrm{~m}$. For all species surveyed, maximum height per plot was measured and dominance was estimated in terms of percentage accuracy. For uncertain taxa, we collected plant vouchers and identified them by comparison with plant material from the herbarium of Cochabamba (BOLV) and in consultation with specialists. Air-dried soil samples were crushed and sieved (2-mm). We measured soil $\mathrm{pH}$ in calcium chloride $(20 \mathrm{~g}$ soil, $50 \mathrm{ml}$ $0.1 \mathrm{~mol} / \mathrm{KCl}$ ) and determined soil electrical conductivity (EC) in water ( $20 \mathrm{~g}$ soil, $\left.50 \mathrm{ml} \mathrm{H}_{2} \mathrm{O}\right)$. Soil texture was estimated by finger testing and by identifying visible features of moist soil samples (Boden 1994). Total carbon and nitrogen contents were analyzed using a CN-analyzer (Vario EL, ELEMENTAR).

Ethnobotanical data sampling and classification

Furthermore, we analyzed and classified plant-related economic and socio-cultural variables, such as the use and valuation of plants, as a basis for comprehending the knowledge of local people with regard to 60 woody species that were either surveyed in the study plots ( $n=46$ species of 58 ) or additionally mentioned as useful plants by local informants $(n=14$ species).

We chose a stepwise methodological procedure to gather local plant knowledge of a representative group of the community of Tres Cruces. In December 2005, data sampling started with two "walks-in-the-woods" (Phillips and Gentry 1993a) next to our vegetation survey plots. Each 3-h walk was guided by a local peasant who explained vernacular names and uses of local woody plants growing in their natural habitats. As participants utilize numerous attributes for recognizing plants, the walk-in-the-woods approach is reliable but time-consuming, and it only allows for a small number of participants (Thomas et al. 2007). For these reasons, we complemented our data sampling with ten semi-structured individual interviews about vernacular names and uses of woody plants with local peasants and three group interviews $(n=7-12$ participants). Fresh plant specimens were used to optimize plant recognition. In addition, we conducted "freelisting interviews" (Quinlan 2005) with local families between December 2007 and January 2008 about actual uses and the cultural importance of plants. Freelisting is a well-established ethnographic method defined as "listing things in a domain in whatever order they come to mind" (Quinlan 2005, p 1), and thus allows for identifying the informants' most salient items. It was thus considered a suitable method for discovering plants that were frequently used by the informants, but not detected in our vegetation survey plots because they grew rarely or not at all in the study area. The freelisting interviews were accompanied by participatory mapping of the communal territory and participatory observation of families' plant uses (e.g., construction materials, medicinal plants in home gardens). The languages employed were either Spanish or Quechua (support of interpreter). The interviews were taped, translated (Quechua to Spanish), and transcribed. Vernacular plant names were related to scientific names in accordance to IPNI (2011), and some unknown plant terms were identified in the herbarium of Cochabamba (BOLV).

We then registered the plant uses of the given woody species. Based on local taxonomy, we regarded the varieties of Cestrum parqui with different phenotypes (flower colors) and chemical-pharmacological properties (toxicity) as distinctive species. On the basis of local plant use categorization and considering the plant use classification of Cook (1995), we grouped all plant uses into eleven use categories: (1) construction, (2) tools, (3) fuel, (4) food (incl. beverage), (5) fodder, (6) medicine (incl. spiritual healing), (7) environmental use (e.g., soil management), (8) field tools (e.g., fence, shelter), (9) domestic use (e.g., kitchenware, furniture), (10) social/spiritual use (rituals, ornaments) and (11) commercialization. Within each use category, different use types per plant were registered, resulting in open lists (e.g., foodspecific use types of Clinopodium bolivianum: herbal tea, spice). A classification developed by Arrázola et al. (2002) supported categorizing of medicinal use types.

Data on perceived negative plant attributes, such as toxicity or weediness, were registered as well, and 
were considered as additional information in the final discussion of the evaluation of most suitable agroforestry plants.

Ecological, economic, and socio-cultural plant values

Based on our data recorded in vegetation studies, we calculated the ecological apparency for each of the woody species surveyed ( $n=58$ species) by using the index "Importance Value" (IV), which is frequently applied in phytosociological (e.g., Boom 1986) and ethnobotanical studies (e.g., Lucena et al. 2007). IV is usually measured in terms of relative frequency (RtF), relative dominance (RtDo), and relative density (RtD) (e.g., Boom 1986; Lucena et al. 2007). As we considered different life-forms, RtD was not regarded as meaningful. Instead, relative height $(\mathrm{RtH})$ contributes to ecological apparency (Phillips and Gentry 1993b). Thus, we calculated IV by using the modified formula IV = RtDo + RtF + RtH, in which RtF was the plant occurrence number divided by the total number of occurrences. RtDo was calculated as species basal area divided by the total basal area; $\mathrm{RtH}$ was calculated as species average maximum height divided by the total number of average maximum heights for all species. IV values were between 0 (not ecologically apparent) and 300 (most ecologically apparent).

After that, we calculated ecological values for each of the woody plants considered in the ethnobotanical data sampling ( $n=60$ species) in order to predict their potential positive and negative ecological effects on soil and biodiversity in agroforestry systems. For this purpose, we developed and applied the "Ecological Plant Value" (EV) approach by using data from secondary sources (Fjeldså and Kessler 1996; ISSG 2011; Killeen et al. 1993; Mahboubi et al. 1997; MBG 2011; Reynel and Léon 1990; Torrico et al. 1994). Being (1) native to and (2) characteristic of natural woodlands, as well as the potentials for contributing to (3) soil fertility and (4) erosion and wind control were classified as species attributes with positive effects on biodiversity and soil conservation. In contrast, being a (5) exotic and probably invasive species or (6) allelopathic or soil-degrading species were evaluated as attributes with potential negative effects. Per species, EV was calculated and categorized according to Table 1 .

In order to assess social plant values, ethnobotany provides suitable indices for collecting relevant qualitative information and translating it into quantifiable data (Phillips and Gentry 1993a). For each of the woody plants considered in ethnobotanical data sampling ( $n=60$ species), we calculated the economic (subsistence and commercial) value by using the Relative Importance (RI) index (Bennett and Prance 2000, modified by Albuquerque et al. 2006). RI measures plant use numbers independently of the level of agreement among informants ("informant consensus", e.g., Phillips and Gentry 1993a), and can therefore be applied to data sampled by using different ethnobotanical methods, as was done in our study. As a first step, we identified the sum of use categories and use types of each species. RI was then calculated based on the formula RI $=$ NUC $+\mathrm{NT}$, in which NUC was

Table 1 Calculation of ecological plant value (EV) $(n=60$ species)

\begin{tabular}{|c|c|c|c|c|c|}
\hline Index & Elements & $\begin{array}{l}\text { Rating of } \\
\text { elements }\end{array}$ & $\begin{array}{l}\text { Index } \\
\text { group }\end{array}$ & Index value & Definition \\
\hline \multirow[t]{5}{*}{ EV } & Beneficial attributes: & $0-1$ & & & Ecological plant value: \\
\hline & $\begin{array}{l}\text { (1) Native; (2) characteristic of woodlands; } \\
\text { (3) contribution to soil fertility; } \\
\text { (4) contribution to erosion and wind control }\end{array}$ & & 1 & 4 & Highly beneficial \\
\hline & \multirow[t]{2}{*}{ Risky attributes: } & & 2 & $2-3$ & Moderately beneficial \\
\hline & & & 3 & $0-1$ & Low/no beneficial effects \\
\hline & (5) Invasive; (6) allelopathic or soil degrading & & 4 & $<0$ & Risky \\
\hline
\end{tabular}

$\mathrm{EV}$ is composed of six elements: four beneficial and two risky plant attributes. Each attribute was rated from 0 (no) to 1 (yes). Based on benefits per species added up and risks subtracted, EV ranges from -2 (risky) to 4 (highly beneficial). On this basis, species were categorized into four EV groups 
the number of use categories of a species divided by the total number of use categories of the most useful species and NT was the number of use types attributed to a species divided by the total number of use types of the most useful species. RI values ranged from 0 (not useful) to 2 (most useful) (Albuquerque et al. 2006).

As RI is based on plant use numbers and is independent of informant consensus, the index does not consider socio-cultural functions of plants (Albuquerque et al. 2006). For this reason, we additionally calculated socio-cultural values for each of the woody plants considered in ethnobotanical data sampling ( $n=60$ species) by using the "Identified Cultural Influence" (ICI) index (Garibaldi and Turner 2004). Based on our own ethnobotanical data complemented by data from Aguilar (1997) and Ponce (2003), ICI was calculated considering species' (1) intensity of use, (2) multiplicity of use, (3) use in language or as indicator, (4) role in narratives and ceremonies or symbolism, (5) persistence of use, (6) irreplaceability, and (7) use as a trade item (see Table 2). The higher the ICI rating (maximum 35) of a species, the more likely it was to represent a local cultural keystone species.

Taking account of ecological, economic, and sociocultural plant values, these indicators provided the basis for an integrated assessment of most promising agroforestry species.

\section{Statistical analyses}

Statistical analyses were performed using the $\mathrm{R}$ software (R Foundation 2010, version 2.11.1). In order to identify significant environmental site variables that determine floristic compositions of woody species, we applied detrended correspondence analysis (DCA) (R package "vegan", function "decorana") on all plots except for two with deficient samples and those on stony terrace walls, since soil data for the latter were not available ( $n=37$ plots of $42 ; n=54$ species).

Furthermore, we linked environmental, human, and plant-related data. To analyze which phytosociological factors and species traits were correlated with RI, we applied principal component analysis (PCA) (Rpackage "vegan", function "prcomp") with previously logarithmized data (RtDo, RtF, RtH, RI) for 46 woody species. PCA was complemented by linear regression analyses to estimate the extent to which RI was determined by correlating factors. Spearman rank correlations were used to examine whether RI was linked to IV ( $n=46$ species) or ICI ( $n=60$ species), respectively. Underlying species numbers differed because not all species considered in ethnobotanical data sampling were surveyed in vegetation plots, and vice versa.

\section{Results}

Socio-ecological features of local woody vegetation

In our study plots, we surveyed 58 woody species belonging to 15 families (Leguminosae was considered as one family). Asteraceae was the most dominant family, representing $31 \%$ of taxa. Solanum (six species, Solanaceae) and Baccharis (five species, Asteraceae) were the most diverse genera. Shrubs (47\%) were the most dominant life-form. Most species

Table 2 Calculation of Identified Cultural Influence (ICI) $(\mathrm{n}=60$ species)

\begin{tabular}{llllll}
\hline Index & Elements & $\begin{array}{l}\text { Rating of } \\
\text { elements }\end{array}$ & $\begin{array}{l}\text { Index } \\
\text { group }\end{array}$ & Index value & Definition \\
\hline ICI & $\begin{array}{l}\text { (1) Intensity of use; (2) multiplicity of use; } \\
\text { (3) use in language, as indicator; }\end{array}$ & $0-5$ & 1 & $28-35$ & Identified cultural influence: \\
& $\begin{array}{l}\text { (4) role in narratives and ceremonies, } \\
\text { symbolism; (5) persistence of use; }\end{array}$ & & 2 & $21-27$ & High high \\
& (6) irreplaceability; (7) trade item & 3 & $14-20$ & Moderate \\
& & 4 & $7-13$ & Low \\
& & 5 & $0-6$ & No
\end{tabular}

ICI is composed of seven elements, each of which is rated from 0 (no) to 5 (yes, very high). Added up, ICI ranges from 0 (no) to 35 (very high) per species. On this basis, species were categorized into five ICI groups 
were naturally growing native species (91\%), of which $32 \%$ grew exclusively in the agro-ecological production zone ura, $13 \%$ grew in chawpi, $28 \%$ occurred exclusively in pata, and $27 \%$ were distributed across two or all agro-ecological production zones. Four percent were cultivated native species (e.g., Buddleja coriacea) not locally grown, but originating from Bolivia, and 5\% were exotic. Baccharis dracunculifolia, Cestrum parqui, and Lepechinia graveolens were among the most dominant and frequent woody species and had the highest IV. Exotic trees such as Eucalyptus globulus had the highest RtH, but the native Polylepis subtusalbida and Schinus molle reached high RtH values as well (Table A.5 in Appendix Supplementary material).

Results from the DCA showed a high eigenvalue (0.82) for axis 1, which indicated good species dispersion along the axis and explained $49.7 \%$ of total variance. Axis 2 showed an eigenvalue of 0.39 and explained $23.2 \%$ of variance. Altitude $(r=$ $-0.999, p \leq 0.001)$ and soil $\mathrm{pH}_{\mathrm{KCl}}(r=0.998$, $p \leq 0.001)$ correlated most with axis 1 . Hence, they were the most determining environmental factors for species distribution. $\mathrm{C} / \mathrm{N}$ ratios correlated significantly ( $p \leq 0.01)$ more with axis $1(r=-0.776)$ than with axis $2(r=0.630)$. Soil EC correlated with axis 2 $(r=0.936, p \leq 0.05)$. Inclination showed a weak tendency towards axis $2(r=0.846, p=0.058)$, and soil texture and exposition did not correlate significantly ( $p>0.05$ ) with axis 1 or axis 2 (Fig. 2).

Peasants in the study site assessed most plants as useful $(95.0 \%, n=57$ species of 60$)$. Table 3 shows a rather uniform distribution of species citations among use categories, except for the less cited social/spiritual use and commercialization. The most cited uses were for medicine, fodder, fuel, and environmental uses. Fodder and fuel were also most diverse in species. Within the use categories, 68 use types were registered. The most diverse use categories in terms of numbers of use types were domestic uses $(n=16)$ and medicine $(n=11)$. Fifty percent of use types were based on timber use, $45 \%$ on the use of leaves, flowers, and fruits, and $5 \%$ on tree crown use (Table A.6 in Appendix Supplementary material). Besides their material uses, plants had cultural roles, such as in naming places (e.g., Prosopis laevigata: "thaqo loma"), as phenological indicators (e.g., Prosopis laevigata: fructification indicates corn productivity), in rituals (e.g., Schinus molle: spiritual healing), or in

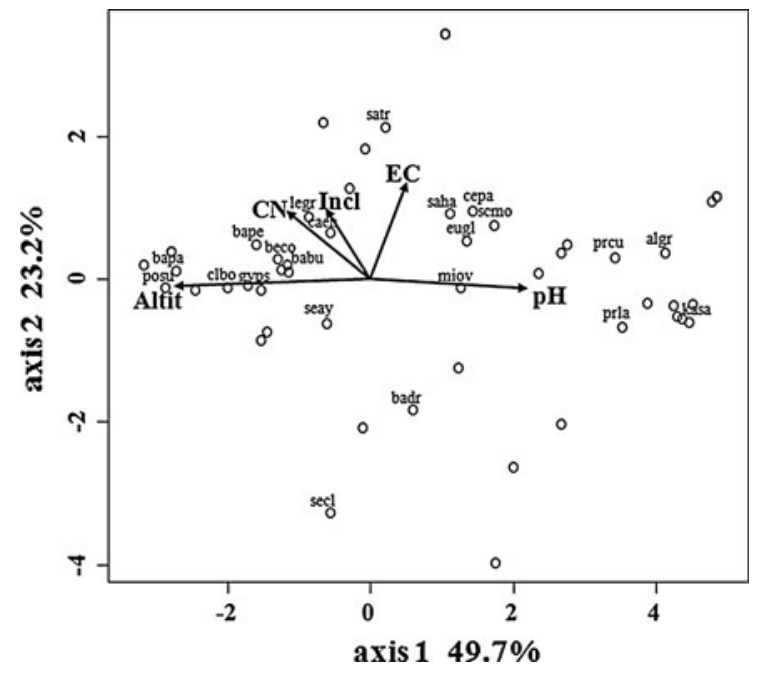

Fig. 2 Detrended correspondence analysis (DCA) of woody species $(n=54)$ and site variables of 37 plots (only significantly correlated variables and those with weak tendencies towards axes were plotted). Vectors: Altit: altitude [m a.s.1.], $\mathrm{CN}$ : total soil carbon [\%]/nitrogen [\%], EC: soil EC $[\mu \mathrm{s}]$, Incl: inclination $\left[{ }^{\circ}\right], \mathrm{pH}$ : soil acidity $\left(\mathrm{pH}_{\mathrm{KCl}}\right)$. Data points of multifunctional species with RI $>0.5$ labelled by abbreviated names (algr: Aloysia gratissima, amar: Ambrosia arborescens, babu: Baccharis buxifolia, badr: Baccharis dracunculifolia, bapa: Baccharis papillosa, bape: Baccharis pentlandii, beco: Berberis commutata, buco: Buddleja coriacea, caen: Calceolaria engleriana, cepa: Cestrum parqui, clbo: Clinopodium bolivianum, eugl: Eucalyptus globulus, gyps: Gynoxys psilophylla, kasa: Kaunia saltensis, legr: Lepechinia graveolens, miov: Minthostachys ovata, posu: Polylepis subtusalbida, prcu: Proustia cuneifolia, prla: Prosopis laevigata, prpe: Prunus persica, saha: Salvia haenkei, sape: Sambucus peruviana, satr: Salpichroa tristis, scmo: Schinus molle, seay: Senna aymara, secl: Senecio clivicolus)

narratives and beliefs (e.g., Schinus molle: death after planting).

In addition to the numerous beneficial functions of plants, peasants also mentioned negative plant attributes, such as leaf toxicity to livestock (Cestrum parqui, Kageneckia lanceolata), and attributes such as thorns and spines (e.g.,, Prosopis laevigata), which were perceived controversially, as they were beneficial in fences, but could also cause injuries and decreased the plant's palatability (Table A.5 in Appendix Supplementary material).

Plant values and factors controlling usefulness

Polylepis subtusalbida was ecologically most beneficial, because this endemic and vulnerable tree is 
Table 3 Numbers of relative citation (\# citation) of use categories [\%], and species attributed (\# species) to use categories [\%] $(n=60$ species $)$

\begin{tabular}{|c|c|c|c|c|c|c|c|c|c|c|c|c|}
\hline Use category & all & com & con & dom & env & fie & fod & food & fuel & med & soc & tool \\
\hline \# Citation [\%] & 100.0 & 1.7 & 8.0 & 9.9 & 11.1 & 10.8 & 12.7 & 6.4 & 11.6 & 15.7 & 1.9 & 10.2 \\
\hline \# Species [\%] & 95.0 & 10.0 & 36.7 & 43.3 & 55.0 & 40.0 & 70.0 & 25.0 & 66.7 & 50.0 & 10.0 & 25.0 \\
\hline
\end{tabular}

Use categories: all all uses, com commercialization, con construction material, dom domestic use, env environmental use, fie field use, fod fodder, food, fuel, med medicine, soc social/spiritual use, tool

characteristic of high-Andean woodlands and has beneficial soil-related attributes. Alnus acuminata, Schinus molle, and Prosopis laevigata were also ecologically valuable. In contrast, Eucalyptus globulus was assessed as most unsuitable for use in agroforestry systems due to its high absorption rate of soil nutrients and moisture, its allelopathic effects on crops, and its potential to invading the natural vegetation (Tables 4, A.5 in Appendix Supplementary material).

Based on the high numbers of use categories and use types, Schinus molle, Prunus persica, Eucalyptus globulus, Prosopis laevigata, and Baccharis dracunculifolia had the highest RI values, and except for Prunus persica also the highest ICI values. They were not easily replaceable due to their multifunctionality (e.g., Schinus molle: 31 use types), use quality (e.g.,
Prosopis laevigata: tools, Eucalyptus globulus: construction) and intensity of use (e.g., Baccharis dracunculifolia: field uses). Schinus molle and Prosopis laevigata had unique cultural roles, and timber of Prosopis laevigata was even bartered with neighboring peasant communities. However, only exotic tree timber (e.g., Eucalyptus globulus) provided monetary value. Despite their lower socio-cultural values, Berberis commutata, Buddleja coriacea, Polylepis subtusalbida and Sambucus peruviana also provided multiple uses (Table 4). In general, culturally influential species also demonstrated high numbers of use categories and use types, and consequently, high RI values (Table A.7a-b in Appendix Supplementary material). This resulted in a highly significant strong correlation between RI and ICI $(R=0.87$, $p<0.001)$.

Table 4 Woody species with highest ecological (EV), economic (RI), and socio-cultural (ICI) values

\begin{tabular}{lllllllc}
\hline$\#$ & Species & EV & $\#$ & Species & RI & $\#$ & Species \\
\hline 1 & Alnus acuminata & 4 & $\mathbf{1}$ & Schinus molle & $\mathbf{2 . 0 0}$ & $\mathbf{1}$ & Prosopis laevigata \\
2 & Escallonia resinosa & 4 & 2 & Prunus persica & 1.42 & $\mathbf{2}$ & Schinus molle \\
$\mathbf{3}$ & Polylepis subtusalbida & $\mathbf{4}$ & 3 & Eucalyptus globulus & 1.41 & 3 & Eucalyptus globulus \\
$\mathbf{4}$ & Prosopis laevigata & $\mathbf{4}$ & $\mathbf{4}$ & Prosopis laevigata & $\mathbf{1 . 4 1}$ & $\mathbf{4}$ & Baccharis dracunculifolia \\
$\mathbf{5}$ & Schinus molle & $\mathbf{4}$ & $\mathbf{5}$ & Baccharis dracunculifolia & $\mathbf{1 . 3 8}$ & 5 & Clinopodium bolivianum \\
6 & Acacia visco & 3 & 6 & Berberis commutata & 1.19 & 6 & Lepechinia graveolens \\
$\mathbf{7}$ & Baccharis dracunculifolia & $\mathbf{3}$ & 7 & Buddleja coriacea & 1.15 & $\mathbf{7}$ & Polylepis subtusalbida \\
8 & Berberis commutata & 3 & $\mathbf{8}$ & Polylepis subtusalbida & $\mathbf{1 . 1 5}$ & 8 & Prunus persica \\
9 & Buddleja coriacea & 3 & 9 & Sambucus peruviana & 1.15 & 9 & Kageneckia lanceolata \\
10 & Dodonaea viscosa & 3 & 10 & Clinopodium bolivianum & 1.05 & 10 & Sambucus peruviana \\
11 & Gynoxys psilophylla & 3 & 11 & Pinus sp. & 1.02 & 11 & Calceolaria engleriana \\
12 & Kageneckia lanceolata & 3 & 12 & Gynoxys psilophylla & 0.96 & 12 & Cestrum parqui (amarillo) \\
13 & Kenthrothamnus weddelianus & 3 & 13 & Lepechinia graveolens & 0.95 & 13 & Kenthrothamnus weddellianus \\
14 & Plazia daphnoides & 3 & 14 & Baccharis papillosa & 0.93 & 14 & Pinus sp. \\
15 & Proustia cuneifolia & 3 & 15 & Kaunia saltensis & 0.93 & 15 & Salvia haenkei \\
16 & Salix humboldtiana & 3 & 16 & Proustia cuneifolia & 0.93 & 16 & Spartium junceum \\
17 & Senna aymara & 3 & 17 & Senna weddelliana & 0.93 & 17 & Passiflora spp. \\
\hline
\end{tabular}

The most promising agroforestry species were identified based on high integrated plant values (bold) 
Economically and culturally influential woody plants were also among the most apparent, reflected by highly significant correlations between ICI and IV ( $R=0.76, p<0.001)$ as well as between RI and IV ( $R=0.71, p<0.001)$. Culturally most influential plants occurred exclusively in the agro-ecological production zone $u r a$, but moderately culturally influential plants were also surveyed in chawpi and pata. Trees and shrubs showed moderate and high cultural influence, whereas subshrubs and perennial herbs had lower socio-cultural values on average (Table A.7b in Appendix Supplementary material). This corresponded with the results of PCA for determining whether phytosociological factors (RtF, RtDo) or species traits (RtH, life-form) correlated with usefulness and economical value (RI) and, consequently, with cultural influence. The analyses resulted in $37.4 \%$ of variance for the first axis (highest rotation: $\mathrm{RI}=0.56$, RtH $=0.51$ ), and $30.0 \%$ for the second axis (highest rotation: $\mathrm{RtF}=-0.58$, RtDo $=-0.53$ ). High correlations were shown between RtH and the life-form "tree", as well as between RtF and RtDo (Fig. 3). Post hoc linear regression analyses resulted in a higher relationship of RI with RtH $\left(R^{2}=0.53\right)$ than with RtDo $\left(R^{2}=0.34\right)$ (adjusted values, $\left.p<0.001\right)$. Hence, economic and socio-cultural value of woody plants increased with rising plant height and timber

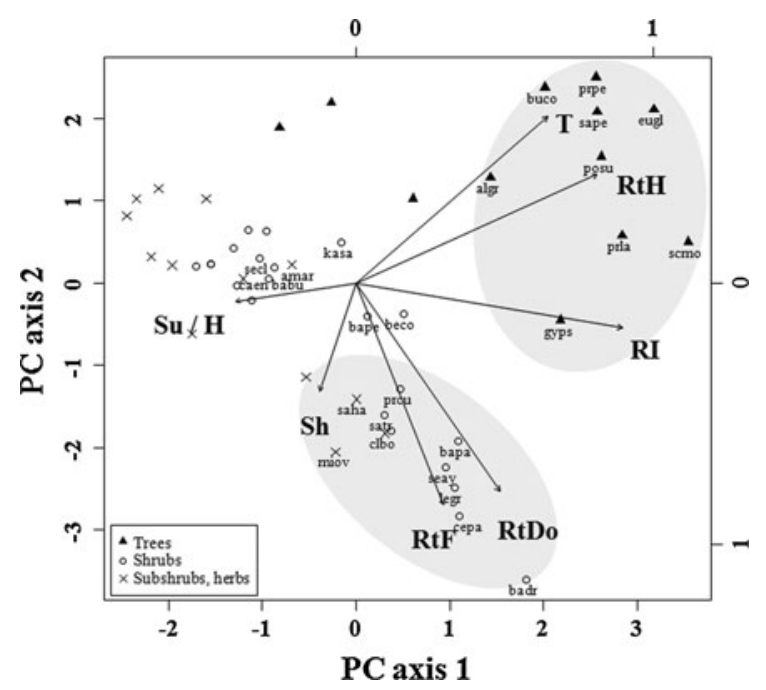

Fig. 3 Principal component analysis (PCA) of usefulness (RI), phytosociological data (RtF, RtDo) and traits (RtH, life-form) of local woody species $(n=46)$. Life-form: tree $(\mathrm{T})$, shrub (Sh), subshrubs/herbs $(\mathrm{Su} / \mathrm{H})$. Data points of multifunctional species with RI $>0.5$ labelled by abbreviated names (see Caption of Fig. 2) availability. In comparison, phytosociological factors such as RtF and RtDo played a minor, but still significant, role in plant valuation.

In summary, the species with the highest integrated values, assessed as being the most promising agroforestry plants, were Schinus molle, Prosopis laevigata, Polylepis subtusalbida, and Baccharis dracunculifolia (Table 4).

\section{Discussion}

Woody vegetation shaped by altitude, agropastoral land use, and subsistence plant use

Floristic compositions reflected around five times higher RtF and RtDo values for (sub-) shrubs than for trees. This was in line with the low frequency and dominance determined for Polylepis subtusalbida trees characteristic of high-Andean woodlands, which were mostly replaced by seral stages of grass- and shrublands due to human-induced processes such as grazing, burning, and timber use (Hensen 2002; Navarro et al. 2005; Thomas et al. 2010a). This is why Baccharis papillosa and Clinopodium bolivianum were frequently present in our study plots of the agro-ecological production zone pata, as they are characteristic species of grasslands situated above 3,500 m a.s.1. (Navarro and Maldonado 2002), along with Gynoxys psilophylla, which is representative for field edges and fallows (Hensen 2002). A mosaic of degraded forest relicts and seral grass- and shrublands also characterized the vegetation of our study area in chawpi and ura that refers to the upper part of Andean dry valleys. Schinus molle and Prosopis laevigata were the only characteristic woodland taxa surveyed, while the most dominant species were Kentrothamnus weddellianus and Baccharis dracunculifolia, which are characteristic of seral shrublands situated below 3,500 $\mathrm{m}$ a.s.l. (Navarro and Maldonado 2002). The dominant and frequently growing woody species surveyed in our study area represent plant types adapted to local traditional agro-pastoral land use, as they are characterized by specific survival strategies, such as quickly developing extensive roots (e.g., Baccharis sp.) or production of plant toxins (e.g., Cestrum parqui) (Ruthsatz and Fisel 1984). We conclude that cultivating woody plants that are wellsuited to agro-pastoral land use may advance the 
successful establishment and maintenance of Andean agroforestry systems-provided that they are not perceived negatively in ecological (e.g., poisonous) or socio-cultural terms (e.g., Schinus molle: belief in death after planting, see above) — and should therefore be considered in all activities. In particular the potential use of native shrubs is worth considering more closely.

Apart from human-induced factors, altitude was shown to be a most significant factor for floristic composition as well, not only in our study area but also in an adjacent region (Thomas et al. 2010a). In addition, soil $\mathrm{pH}_{\mathrm{KCl}}$ (acidity) inversely and highly significantly correlated with altitude. This was possibly an effect of decreasing temperature (e.g., Alexander et al. 1993) and thus decreasing decomposition rates and higher leaching intensities based on lower evapotranspiration rates at higher altitudes. $\mathrm{C} / \mathrm{N}$ showed rising ratios with increasing altitude, possibly due to decelerating organic $\mathrm{C}$ turnover. However, plant litter quality and quantity also played crucial roles in regulating $\mathrm{C} / \mathrm{N}$ ratios (Dahlgren et al. 1997). Our data therefore reflected that climatic factors strongly controlled soil properties and vegetation types, which in turn were also shaped by mutual soil-vegetation interactions. With regard to Andean agroforestry, our results emphasize that selecting species suited to altitude-dependent climatic and edaphic conditions is a crucial factor of successful management.

Regarding local plant-related livelihood needs and uses, as much as $95 \%$ of plant use types registered in our study area focused on meeting domestic (e.g., fuel, construction) and agro-pastoral subsistence needs (e.g., fodder, tools), which is characteristic of smallholder farming systems that usually focus on multifunctional production (Wiersum 2004). In contrast, only $5 \%$ of plant use types represented commercial uses. Especially Eucalyptus had promising commercial values due to its dominance in Andean timber markets (Chepstow-Lusty and Winfield 2000). Along with high subsistence values (e.g., construction, fuel, medicine), these commercial values accounted for Eucalyptus' high local economic and socio-cultural values. By contrast, in spite of the promising characteristics of some species such as the fast-growing Alnus acuminata, the timber of native trees does not provide monetary values (Ibisch 2002). The main reason for this is the dominant role of exotic trees in timber markets (Chepstow-Lusty and Winfield 2000). Due to this absence of promising monetary returns, we concluded that time- and labor-intensive establishment and management of native agroforestry trees would hardly be adopted and refined by local land users, especially in view of continuously declining soil productivity and the unfavorable macroeconomic conditions that force Andean peasants to increasingly spend labor on non-farming activities in order to earn additional income (Zimmerer 1993). The lack of markets for agroforestry timber and non-timber products is not only a Bolivian but a common problem (Langenberger et al. 2009), and successful commercialization also depends on peasants' capacity to participate in local and regional trading activities. For all these reasons, we conclude that achieving economic sustainability of Andean agroforestry systems using native species is a key problem, and gaining commercial benefits from native species is quite impossible for peasants without long-term external support. In our view, therefore, under the current conditions it is more feasible to implement less timeand labor-consuming types of agroforestry systems that aim mainly at meeting multifunctional subsistence needs such as fuelwood and fodder plants, described in more detail below. Such agroforestry systems should be given particular consideration.

Approximately $70 \%$ of local woody plants supplied fuel and fodder, respectively. These use categories were thus highly unspecific in terms of the species concerned, but the species utilized were not equally valued. For instance, Baccharis dracunculifolia was favored for use as fuel based on high heating values, and Lepechinia graveolens was appreciated as a highly palatable fodder plant. Apart from the quality of use, peasants also cited plant availability as crucial to preference, which was in line with the ecological apparency hypothesis (Phillips and Gentry 1993b), and was also confirmed by correlating RI and IV in our study. Due to the absence of external energy sources, peasants depend heavily on using fuel plants in order to sustain their livelihoods. At the same time, fuelwood harvesting has been identified as a driving factor for continuing Andean woodland destruction (Thomas et al. 2010b). Similarly, while livestock rearing is an integral part of local agro-pastoral land use, livestock grazing can reduce natural fodder plant regeneration (e.g., Polylepis sp., see Hensen 2002) and may result in soil surface compaction and reduced 
water infiltration (Ruthsatz and Fisel 1984). Fuelwood and livestock grazing are thus important plant uses but conflict with environmental agroforestry goals. Agroforestry systems should therefore focus on providing additional fuelwood and fodder resources in order to reduce the pressure on natural woodlands. Furthermore, we suggest using agroforestry species adapted to livestock grazing (e.g., re-shooting ability), and motivating peasants to apply community-based norms and control mechanisms in order to regulate fuelwood harvesting and livestock grazing and thereby balance use and conservation of fuel and fodder plants.

Not all plant uses are per se plant-destructive. For instance, peasants perceived more than half of local woody species as beneficial to soil productivity; this was especially the case for Lepechinia graveolens, which grows along field margins, as well as Polylepis subtusalbida and Schinus molle, which can even be found in cultivated plots. The organic matter of these species is used as organic fertilizer, in addition to livestock dung. Furthermore, immaterial values (aesthetical, emotional, and spiritual) of the vegetation as a whole were locally recognized. In accordance with Andean beliefs that life is a dynamic interplay of natural-material, social, and spiritual aspects (Rist and Dahdouh-Guebas 2006), woody plants such as Schinus molle were used in rituals, such as q'owa (giving to eat) and ch'alla (giving to drink), in order to maintain positive relationships with Pachamama (Mother Earth) and thereby ensure (re)production and wellbeing. Spiritual beliefs are rooted in the principle of reciprocity (Mathez-Stiefel et al. 2007); accordingly, psychosomatic disorders are believed to be caused by disturbed social or spiritual interrelations. Spiritual healing rituals thus aim at restoring these imbalances (Vandebroek et al. 2004). According to local beliefs, mostly native medicinal woody plants (e.g., Schinus molle, Lepechinia graveolens) possessed beneficial spirits for curing, but cultivated exotic plants (e.g., Eucalyptus globulus, Sambucus peruviana) were assimilated in spiritual healing as well. Half of the local woody species were used as medicinal plants, with most medicinal uses ( $\sim 90 \%)$ directed towards treating somatic diseases such as pains, infections, and gastrointestinal and dermatological disorders. Possibly, emphasizing non-destructive plant uses (e.g., environmental, medicine) and recognizing immaterial plant values (e.g., spiritual) in community-based agroforestry science and practice may motivate local people to manage natural vegetation in a more sustainable way. Moreover, recognizing traditional medicinal knowledge may improve rural health care (Mathez-Stiefel and Vandebroek 2012).

Promising species and implications for agroforestry

The importance of Polylepis trees and woodlands for preserving biological diversity and their unique environmental services, such as absorbing and storing air moisture at high altitudes where no other trees can grow, is widely recognized (Fjeldså and Kessler 1996; Gareca et al. 2010). Alnus acuminata-not surveyed in our study plots-is another high-Andean tree which is well-known as being ecologically valuable. It hosts nitrogen-fixing actinomycetes (Frankia) in its root nodules and therefore improves soil-fertility (Russo 1990). In our study area, Schinus molle and Prosopis laevigata contributed to environmental services in the agro-ecological production zone ura, while Baccharis dracunculifolia was the most widely distributed pioneer and soil-enriching species on fallow plots in all zones. However, rather than specific species, peasants recognized woody species as whole as essential landscape elements which-with the exception of Eucalyptus globulus-improve climatic, soil, and water conditions and, accordingly, ensure successful agro-pastoral production. Summarized, the EV index developed in our study provides useful data for evaluating species' ecological effects. However, it is based on secondary information which is still incomplete. Further experimental ecological studies and data of promising native and exotic agroforestry plants of the Bolivian Andes are therefore needed to improve these insights.

Eucalyptus globulus, Schinus molle, Prosopis laevigata, and Baccharis dracunculifolia were among the species with the highest economic and socio-cultural values due to their beneficial traits (e.g., timber) and high ecological apparency. In contrast, Berberis commutata and Buddleja coriacea also provided high economic values, but exhibited low socio-cultural values. Buddleja coriacea is a recognized native agroforestry tree (e.g., Chepstow-Lusty and Winfield 2000) and has been promoted by rural development initiatives. Local knowledge regarding the use of Buddleja is thus a result of external knowledge transfer. However, the short time period since 
implementation ( $\sim 10$ years) possibly induced low active species uses and cultural assimilation. In contrast, knowledge regarding the use of locally grown Berberis commutata is locally rooted. Low abundance and accessibility, unfavorable spines, and out-dated use types (e.g., coloration of wool) were among the factors responsible for low use intensities of Berberis. RI and ICI values correlated significantly based on usefulness as a shared crucial plant attribute. Nevertheless, in our study Buddleja and Berberis demonstrated that using RI and ICI was complementary, because plant valuation considered use numbers combined with use quality, use intensity, and sociocultural values of plants.

Schinus molle, Prosopis laevigata, Polylepis subtusalbida, and Baccharis dracunculifolia were identified as the most promising agroforestry species based on high integrated plant values within the given socioecological context. In comparison, Escallonia resinosa and Alnus acuminata provide high ecological values and potential usefulness as well (e.g., Chepstow-Lusty and Winfield 2000; Torrico et al. 1994), but only received low economic and socio-cultural values as they were sparsely distributed in our study area. Their importance would perhaps increase if they were promoted, but - as already shown by Buddleja and Berberis - this is highly dependent on how much their plant uses effectively contribute to livelihoods. On the contrary, both Eucalyptus globulus and Prunus persica received high economic and socio-cultural values but low ecological values as they were exotic species and, in the case of Eucalyptus, soil- and biodiversity-degrading. The negative attributes of plants were not quantified in our study, but must also be considered in plant assessment; this becomes apparent in the case of Kageneckia lanceolata, which is a promising agroforestry tree but locally known to possess leaves that induce poisonous effects to livestock. Overall, plant indices provide useful estimations of plant values (Turner 1988). Integrated in our analytical framework, the plant indices were therefore shown to be suited not only to assess and rank promising agroforestry species, but also to detect ecological and biological plant attributes (e.g., lifeform, dominance) that determined the usefulness of plants in the peasants' perception (Lawrence et al. 2005). This in turn leads to a better understanding of environment-human-plant relationships, which is the basis for identifying most promising plant traits and species in accordance with peasants' needs and environmental adaptation.

In summary, using our analytical framework helped to identify the most promising agroforestry species. However, as shown by the example described further below, relying exclusively on quantitative assessment as expressed in the analytical framework discussed here bears the risk of any model, in the sense that it can represent part, but never the full range of socioecological complexities involved in issues of sustainable development. A careful re-contextualization of quantitative data achieved using an analytical framework with complementary qualitative data is therefore recommended. The need for such re-contextualization is evident in the case of the use of Polylepis in agropastoral systems, which is controversial despite this species' high integrated values. Indeed, agricultural production benefits from Polylepis based on the fertile organic matter produced by its foliage or on its ability to create more favorable microclimatic conditions (e.g., Fjeldså 2002). On the other hand, however, Hensen (2002) reported that Polylepis can also have negative effects on crops due to light or root competition. Moreover, livestock grazing is in conflict with the natural regeneration of Polylepis.

In our study area, Polylepis trees were rare and grew in places distant from inhabited and cultivated areas. Their high ecological plant values from a scientific perspective (e.g., Fjeldså 2002) were therefore hardly recognized by peasants, who additionally reported that previous efforts of Polylepis cultivation had not succeeded. However, peasants also stated that Polylepis had recently regenerated in uncultivated ravines and slopes due to reduced harvesting pressure since the establishment of exotic trees. From this perspective, even Eucalyptus plantations may contribute to preserving natural woodlands, as they help to reduce the exploitation of native species. However, great care must be taken as to how and where they are planted in order to prevent soil degradation (Fjeldså 2002). Moreover, if native species are less used and replaced by cultivated trees, this also decreases their perceived value (Lawrence et al. 2005), which in turn may affect local tree conservation. In our study area, only access to useful woody plants was restricted by community-based norms and rules, which are important tools for regulating native tree timber uses (Mariscal and Rist 1999). By using Polylepis as an example, our study also showed that the decline in 
timber harvest due to alternative fuel sources may also support woody species' natural succession, especially when associated with communal regulations of livestock grazing and fire control. Furthermore, natural succession of valuable species can be stimulated by enhancing their reproductive potential through specific management practices (e.g., weeding, mulching) or by dispersing their seeds and seedlings (Wiersum 2004). In our study area, controlled plant regeneration of Schinus molle was already being practised by local peasants because they particularly appreciate this species for storing fodder in its crown and for its providing shade. Nonetheless, it was only rarely cultivated. One reason for this was that local knowledge of native plant propagation was generally low in the study area; an additional reason probably was that spiritual beliefs hold the planting of Schinus molle responsible for causing death. In view of this example, we suggest that making use of the successional processes in agroforestry is an effective alternative to tree cultivation.

\section{Conclusion}

This paper presents an analytical framework for integrated socio-ecological assessment of agroforestry species and describes how this framework was empirically tested, helping to identify most promising agroforestry species within the locally existing range of woody species in an indigenous peasant community of the Andean highlands of Bolivia. Emphasis was placed on integrating ecological, socio-economic, and cultural aspects as well as on considering scientific and indigenous knowledge alike. Application of the analytical model to evaluate 60 woody species occurring in the study area showed that Schinus molle, Prosopis laevigata, Polylepis subtusalbida, and Baccharis dracunculifolia can be considered as the most promising agroforestry species in this area. However, interview data and participatory observations also indicated that economic, technical, practical, and socio-cultural obstacles impede the cultivation of these native species in agroforestry systems. As complementary or alternative practices to cultivation, enhancing the reproductive potentials of natural woody vegetation and selected valuable species should therefore be considered. Numerous speciesespecially shrubs (e.g., Lepechinia graveolens,
Kaunia saltensis) and subshrubs (e.g., Minthostachys ovata, Clinopodium bolivianum) — contribute to meeting subsistence needs, offer environmental benefits, and foster emotional and spiritual well-being; some even have commercial potentials (e.g., Alnus acuminata). Agroforestry should therefore pay attention to the management of all adapted interstitial species and vegetation types that grow along with agro-pastoral systems (Backes 2001) rather than focusing only on the cultivation of selected woody species. Furthermore, our work shows that it is necessary to break conceptual barriers, not only between social and natural sciences but also between the local knowledge of peasants and the external knowledge of scientists and development experts. This requires an intimate understanding of the realities of peasants' livelihoods and recognition of their ecological knowledge, as well as their integration as equal partners into horizontal dialogues based on mutual learning between sciencebased and local knowledge and practices. Furthermore, such a transdisciplinary approach allows for recognizing and making more systematic use of previously unknown local potentials, such as local norms and plant management techniques, as well as the often-ignored cultural and spiritual plant values, for improving community-based agroforestry science and practice.

Acknowledgments We greatly appreciate the financial support received from the Andrea-von-Braun-Stiftung in Munich, Germany. Our most sincere thanks go to the syndicate assembly of Tres Cruces and the local leaders of the sub-central Waka Playa for authorizing our research, and to all local peasants who facilitated the study with confidence and ready cooperation. We are also thankful for the technical assistance of the BioAndes conservation and development program, funded by the Swiss Agency for Development and Cooperation (SDC). Moreover, we would like to acknowledge the scientific support of the Swiss National Centre of Competence in Research (NCCR) NorthSouth: Research Partnerships for Mitigating Syndromes of Global Change, a research program co-funded by the Swiss National Science Foundation (SNSF), SDC, and the participating institutions. Furthermore, we are thankful to the Bolivian National Meteorology and Hydrology Service (SENAMHI), Cochabamba, for providing climatic data, as well as to Magaly Mercado and the working team of the herbarium of Cochabamba (BOLV) for their support in plant identification. We are very grateful to our colleagues Sarah-Lan Mathez-Stiefel (CDE), Rolando Sánchez, Sonia Medrano, Roger Juárez, Deicy Mejía (AGRUCO), Michael Beckmann, Christine Voigt, Catharina Landschulz, Ronny Warzecha, and Heidi Hirsch (MLU) for cooperating in field studies, interview translation, soil analyses, and graphic presentation. Finally, we would like to acknowledge Marlène Thibault and Danny McCluskey for proofreading the 
manuscripts, and the anonymous reviewers who have contributed to improving this paper.

\section{References}

Aguilar LC (1997) Predicción del tiempo y su influencia en la organización de la producción en la comunidad de Tres Cruces, provincia Tapacarí. Tesis de licenciatura. AGRUCO, Universidad Mayor de San Simón, Cochabamba

Aguilar LC, Bracamonte R (2002) Diagnóstico participativo y plan de ordenamiento predial de la comunidad Tres Cruces. AGRUCO, Municipio Tapacarí, Cochabamba

Ahmed P (1989) Eucalyptus in agroforestry: its effects on agricultural production and economics. Agrofor Syst $8: 31-38$

Alavalapati JRR, Shrestha RK, Stainback GA, Matta JR (2004) Agroforestry development: an environmental economic perspective. Agrofor Syst 61:299-310

Albuquerque UP, Lucena RFP, Monteiro JM, Florentino ATN, Almeida C (2006) Evaluating two quantitative ethnobotanical techniques. Ethnobot Res Appl 4:51-60

Alexander EB, Mallory JI, Colwell WL (1993) Soil-elevation relationships on a volcanic plateau in the southern Cascade Range, northern California, USA. Catena 20:113-128

Arrázola S, Atahuachi M, Saravia E, Lopez A (2002) Diversidad florística medicinal y potencial etnofarmacológico de las plantas de los valles secos de Cochabamba, Bolivia. Rev Boliv Ecol Conserv Ambient 12:53-85

Backes MM (2001) The role of indigenous trees for the conservation of biocultural diversity in traditional agroforestry land use systems: the Bungoma case study. In situ conservation of indigenous tree species. Agrofor Syst 52:119-132

Bennett BC, Prance GT (2000) Introduced plants in the indigenous pharmacopoeia of northern South America. Econ Bot 54(1):90-102

Boden AG (1994) Bodenkundliche Kartieranleitung. E. Schweizerbart'sche Verlagsbuchhandlung, Stuttgart

Boom BM (1986) A forest inventory in Amazonian Bolivia. Biotropica 18(4):287-294

Butterfield RP (1995) Promoting biodiversity: advances in evaluating native species for reforestation. For Ecol Manag 75:111-121

Chepstow-Lusty A, Winfield M (2000) Inca agroforestry: lessons from the past. Ambio 29(6):322-328

Cook FEM (1995) Economic botany data collection standard. Royal Botanic Gardens Kew, Richmond

Dahlgren RA, Boettinger JL, Huntington GL, Amundson RG (1997) Soil development along an elevational transect in the western Sierra Nevada, California. Geoderma 78:207-236

Fjeldså J (2002) Polylepis forests-vestiges of a vanishing ecosystem in the Andes. Ecotropica 8:111-123

Fjeldså J, Kessler M (1996) Conserving the biological diversity of Polylepis woodlands of the highland of Peru and Bolivia. A contribution to sustainable natural resource management in the Andes. NORDECO, Copenhagen

Gareca EE, Hermy M, Fjeldså J, Honnay O (2010) Polylepis woodland remnants as biodiversity islands in the Bolivian high Andes. Biodivers Conserv 19:3327-3346
Garibaldi A, Turner N (2004) Cultural keystone species: implications for ecological conservation and restoration. Ecol Soc 9(3):1. http://www.ecologyandsociety.org/vol9/iss3/art1/

Gausset Q (2004) Ranking local tree needs and priorities through an interdisciplinary action research approach. J Transdiscipl Environ Stud 3(1):1-17

Hensen I (2002) Impacts of anthropogenic activity on the vegetation of Polylepis woodlands in the region of Cochabamba, Bolivia. Ecotropica 8:183-203

Hernando A, Tejera R, Velázquez J, Núñez MV (2010) Quantitatively defining the conservation status of Natura 2000 forest habitats and improving management options for enhancing biodiversity. Biodivers Conserv 19:2221-2233

Honorable Alcaldía Municipal de Tapacarí (2003) Ajuste del plan de desarrollo municipal Tapacari (PDM) 2003-2007. Programa de Inversión Rural Participativo (PDCR II), AGRUCO, Cochabamba

Ibisch PL (2002) Evaluation of a rural development project in southwest Cochabamba, Bolivia, and its agroforestry activities involving Polylepis besseri and other native species - a decade of lessons learned. Ecotropica 8:205-218

IPNI (2011) The International Plant Names Index. Royal Botanic Gardens Kew, Harvard University Herbaria, Australian National Herbarium. http://www.ipni.org. Accessed 17 July 2011

ISSG (2011) Global Invasive Species Database. Invasive Species Specialist Group. http://www.issg.org/database/welcome. Accessed 3 June 2011

Jose S (2009) Agroforestry for ecosystem services and environmental benefits: an overview. Agrofor Syst 76:1-10

Jose S (2011) Managing native and non-native plants in agroforestry systems. Agrofor Syst 83:101-105

Kidanu S, Mamo T, Stroosnijder L (2005) Biomass production of Eucalyptus boundary plantations and their effect on crop productivity on Ethiopian highland vertisols. Agrofor Syst 63:281-290

Killeen TJ, García E, Beck SG (1993) Guía de árboles de Bolivia. Herbario Nacional de Bolivia, Missouri Botanical Garden, La Paz

Kolar CS, Lodge DM (2001) Progress in invasion biology: predicting invaders. Trends Ecol Evol 16:199-204

Langenberger G, Prigge V, Martin K, Belonias B, Sauerborn J (2009) Ethnobotanical knowledge of Philippine lowland farmers and its application in agroforestry. Agrofor Syst 76:173-194

Lawrence A, Phillips OL, Ismodes AR, Lopez M, Rose S, Wood D, Farfan AJ (2005) Local values for harvested forest plants in Madre de Dios, Peru: towards a more contextualised interpretation of quantitative ethnobotanical data. Biodivers Conserv 14:45-79

Lucena RFP, Araújo E, Albuquerque UP (2007) Does the local availability of woody Caatinga plants (northeastern Brazil) explain their use value? Econ Bot 61(4):347-361

Luzar J (2007) The political ecology of a "forest transition": Eucalyptus forestry in the southern Peruvian Andes. Ethnobot Res Appl 5:85-93

Madge C (1995) Ethnography and agroforestry research: a case study from the Gambia. Agrofor Syst 32:127-146

Mahboubi P, Gordon AM, Stoskopf N, Voroney RP (1997) Agroforestry in the Bolivian Altiplano: evaluation of tree 
species and greenhouse growth of wheat on soils treated with tree leaves. Agrofor Syst 37:59-77

Mariscal JC, Rist S (1999) Tipos de relaciones bosque-comunidad y normas tradicionales de uso y acceso a la vegetación boscosa. El caso de las comunidades de Chorojo y Chullpa K'asa de las provincias Quillacollo y Tapacarí en el departamento de Cochabamba. AGRUCO, PROBONA, Cochabamba

Mathez-Stiefel SL, Vandebroek I (2012) Distribution and transmission of medicinal plant knowledge in the Andean highlands: a case study from Peru and Bolivia. Evid Based Complement Altern Med 2012:1-18

Mathez-Stiefel SL, Boillat S, Rist S (2007) Promoting the diversity of worldviews: an ontological approach to biocultural diversity. In: Haverkort B, Rist S (eds) Endogenous development and bio-cultural diversity: the interplay of worldviews, globalization and locality. COMPAS, CDE, Leusden, pp 67-81

MBG (2011) Tropicos. Missouri Botanical Garden. http:// www.tropicos.org. Accessed 17 July 2011

McDonald MA, Hofny-Collins A, Healey JR, Goodland TCR (2003) Evaluation of trees indigenous to the montane forest of the Blue Mountains, Jamaica for reforestation and agroforestry. For Ecol Manag 175:379-401

McNeely JA, Schroth G (2006) Agroforestry and biodiversity conservation - traditional practices, present dynamics, and lessons for the future. Biodivers Conserv 15:549-554

Navarro G, Maldonado M (2002) Geografía ecológica de Bolivia: vegetación y ambientes acuáticos. Centro de Ecología Difusión Simón I. Patiño, Santa Cruz

Navarro G, Molina JA, De la Barra N (2005) Classification of the high-Andean Polylepis forests in Bolivia. Plant Ecol 176:113-130

Nuñez MA, Simberloff D (2005) Invasive species and the cultural keystone species concept. Ecol Soc 10(1): r4. http:// www.ecologyandsociety.org/vol10/iss1/resp4/

Phillips O, Gentry AH (1993a) The useful plants of Tambopata, Peru: I. Statistical hypotheses tests with a new quantitative technique. Econ Bot 47(1):15-32

Phillips O, Gentry AH (1993b) The useful plants of Tambopata, Peru: II. Additional hypothesis testing in quantitative ethnobotany. Econ Bot 47(1):33-43

Ponce D (2003) Previsión del clima y recreación del conocimiento indígena como estrategia para la conservación de la diversidad cultivada en los Andes bolivianos: el caso de la comunidad de Chorojo, provincia Quillacollo, departamento Cochabamba. Tesis de maestría. AGRUCO, Universidad Mayor de San Simón, Cochabamba

Quinlan M (2005) Considerations for collecting freelists in the field: examples from ethnobotany. Field Methods 17(3):1-16

R Foundation (2010) The R project for statistical computing. http://www.r-project.org. Accessed 24 Sept 2010

Reed MS (2007) Participatory technology development for agroforestry extension: an innovation-decision approach. Afr J Agric Res 2(8):334-341

Reynel C, Léon J (1990) Árboles y arbustos andinos para agroforestería y conservación de suelos. Tomo I: Especies forestales útiles para el productor agropecuario. Tomo II: Las especies. Proyecto FAO Holanda/DGFF, Lima

Richardson DM, Binggeli P, Schroth G (2004) lnvasive agroforestry trees: problems and solutions. In: Schroth G, Da Fonseca GAB, Harvey CA, Gascon C, Vasconcelos HL, Izac AMN (eds) Agroforestry and biodiversity conservation in tropical landscapes. Island Press, Washington, pp 371-396

Rist S, Dahdouh-Guebas F (2006) Ethnosciences-a step towards the integration of scientific and indigenous forms of knowledge in the management of natural resources for the future. Environ Dev Sustain 8:467-493

Russo RO (1990) Evaluating Alnus acuminata as a component in agroforestry systems. Agrofor Syst 10:241-252

Ruthsatz B, Fisel U (1984) The utilization of natural resources by a small community on the highlands of Bolivia and its effects on vegetation cover and site conditions. Erdwiss Forsch 18:211-234

Saunders CD, Brook AT, Myers OE (2006) Using psychology to save biodiversity and human well-being. Conserv Biol 20(3):702-705

Tardío J, Pardo-de-Santayana M (2008) Cultural importance indices: a comparative analysis based on the useful wild plants of southern Cantabria (northern Spain). Econ Bot 62(1):24-39

Thomas E, Vandebroek I, Van Damme P (2007) What works in the field? A comparison of different interviewing methods in ethnobotany with special reference to the use of photographs. Econ Bot 61(4):376-384

Thomas E, Van Damme P, Goetghebeur P (2010a) Some factors determining species diversity of prepuna and puna vegetations in a Bolivian Andes region. Plant Ecol Evol 143(1):31-42

Thomas E, Douterlungne D, Vandebroek I, Heens F, Goetghebeur P, Van Damme P (2010b) Human impact on wild firewood species in the rural Andes community of Apillapampa, Bolivia. Environ Monit Assess 178:333-347

Torrico G, Peca C, Beck SG, García E (1994) Leñosas útiles de Potosí. Proyecto FAO/Holanda/CDF "Desarrollo forestal comunal en el Altiplano boliviano", Potosí

Turner NJ (1988) "The importance of a rose": evaluating the cultural significance of plants in Thompson and Lillooet Interior Salish. Am Anthropol 90:272-290

Vandebroek I, Calewaert JB, De Jonckheere S, Sanca S, Semo L, Van Damme P, Van Puyvelde L, De Kimpe N (2004) Use of medicinal plants and pharmaceuticals by indigenous communities in the Bolivian Andes and Amazon. Bull World Health Organ 82(4):243-250

Wiersum KF (2004) Forest gardens as an 'intermediate' landuse system in the nature-culture continuum: characteristics and future potential. Agrofor Syst 61:123-134

Zhang C, Fu S (2009) Allelopathic effects of Eucalyptus and the establishment of mixed stands of Eucalyptus and native species. For Ecol Manag 258(7):1391-1396

Zimmerer KS (1993) Soil erosion and labor shortages in the Andes with special reference to Bolivia, 1953-91: implications for "conservation-with-development". World Dev 21(10):1659-1675 